p-ISSN: 2503-1228; e-ISSN: 2621-4172

\title{
PENERAPAN METODE PEMBELAJARAN KOOPERATIF MODEL TEAM ASSISTED INDIVIDUALIZATION UNTUK MENINGKATKAN PRESTASI BELAJAR MATEMATIKA SISWA KELAS VII-B SMP NEGERI 2 NGIMBANG TAHUN PELAJARAN 2019/2020
}

\author{
Umi Nurhayati \\ SMP Negeri 2 Ngimbang Lamongan \\ Email : umiii.nurh@gmail.com
}

\begin{abstract}
Abstrak :
Penelitian ini berdasarkan permasalahan: (a) Bagaimanakah peningkatan prestasi belajar siswa dengan diterapkannya metode pembelajaran kooperatif model Team Assisted Individualization? (b) Bagaimanakah pengaruh metode pembelajaran kooperatif model Team Assisted Individualization terhadap motivasi belajar siswa Kelas VII-B SMP Negeri 2 Ngimbang di Kabupaten Lamongan tahun pelajaran 2019/2020? Sedangkan tujuan dari penelitian ini adalah: (a) Untuk mengetahui peningkatan prestasi belajar siswa setelah diterapkannya metode pembelajaran kooperatif model Team Assisted Individualization. (b) Untuk mengetahui pengaruh motivasi belajar siswa setelah diterapkan metode pembelajaran kooperatif model Team Assisted Individualization. Penelitian ini menggunakan penelitian tindakan (action research) sebanyak tiga putaran. Setiap putaran terdiri dari empat tahap yaitu: rancangan, kegiatan dan pengamatan, refleksi, dan refisi. Sasaran penelitian ini adalah siswa Kelas VII-B SMP Negeri 2 Ngimbang. Data yang diperoleh berupa hasil tes formatif, lembar observasi kegiatan belajar mengajar. Dari hasil analisis didapatkan bahwa prestasi belajar siswa mengalami peningkatan dari siklus I sampai siklus III yaitu, siklus I $(65,59 \%)$, siklus II (77,27\%), siklus III (93,31\%). Simpulan dari penelitian ini adalah metode kooperatif model Team Assisted Individualization dapat berpengaruh positif terhadap motivasi belajar siswa Kelas VII-B SMP Negeri 2 Ngimbang, serta model pembelajaran ini dapat digunakan sebagai salah satu alternative dalam pembelajaran matematika.
\end{abstract}

Kata kunci: Metode Pembelajaran Kooperatif Model Team Aassisted Individualization

PENDAHULUAN

Manusia memiliki derajat potensi, latar belakang historis, serta harapan masa depan yang berbeda-beda. Karena adanya perbedaan, manusia dapat silih asah (saling mencerdaskan). Pembelajaran kooperatif 
secara sadar menciptakan interaksi yang silih asah, sehingga sumber belajar bagi siswa bukan hanya guru dan buku ajar tetapi juga sesama siswa.

Manusia adalah makhluk hidup individual, berbeda satu sama lain. Karena sifatnya yang individual, maka manusia yang satu membutuhkan manusia lainnya sehingga sebagai konsekuensi logisnya manusia harus menjadi makhluk sosial, makhluk yang berinteraksi dengan sesamanya. Karena satu sama lain saling membutuhkan maka harus ada interaksi yang silih asih (saling menyayangi atau saling mencintai). Pembelajaran kooperatif merupakan pembelajaran yang secara sadar dan sengaja menciptakan interaksi yang saling mengasihi antar sesama siswa.

Pembelajaran Matematika tidak lagi mengutamakan pada penyerapan melalui pencapaian informasi, tetapi lebih mengutamakan pada pengembangan kemampuan dan pemrosesan informasi. Untuk itu aktivitas peserta didik perlu ditingkatkan melalui latihan-latihan atau tugas matematika dengan bekerja kelompok kecil dan menjelaskan ide-ide kepada orang lain. (Hartoyo, 2000: 24).

Langkah-langkah tersebut memerlukan partisipasi aktif dari siswa.
Untuk itu perlu ada metode pembelajaran yang melibatkan siswa secara langsung dalam pembelajaran. Adapun metode yang dimaksud adalah metode pembelajaran kooperatif. Pembelajaran kooperatif adalah suatu pengajaran yang melibatkan siswa bekerja dalam kelompok-kelompok untuk menetapkan tujuan bersama. Felder, (1994: 2).

Pembelajaran kooperatif lebih menekankan interaksi antar siswa. Dari sini siswa akan melakukan komunikasi aktif dengan sesama temannya. Dengan komunikasi tersebut diharapkan siswa dapat menguasai materi pelajaran dengan mudah karena "siswa lebih mudah memahami penjelasan dari kawannya dibanding penjelasan dari guru karena taraf pengetahuan serta pemikiran mereka lebih sejalan dan sepadan". (Sulaiman dalam Wahyuni 2001: 2).

Penelitian juga menunjukkan bahwa pembelajaran kooperatif memiliki dampak yang amat positif terhadap siswa yang rendah hasil belajarnya. (Nur, 1996: 2).

Pete Tschumi dari Universitas Arkansas Little Rock memperkenalkan suatu ilmu pengetahuan pengantar pelajaran komputer selama tiga kali, yang 
p-ISSN: 2503-1228; e-ISSN: 2621-4172

pertama siswa bekerja secara individu, dan dua kali secara kelompok. Dalam kelas pertama hanya $36 \%$ siswa yang mendapat nilai $\mathrm{C}$ atau lebih baik, dan dalam kelas yang bekerja secara kooperatif ada 58\% dan $65 \%$ siswa yang mendapat nilai $\mathrm{C}$ atau lebih baik (Felder, 1994:14).

Berdasarkan paparan tersebut di atas maka peneliti ingin mencoba melakukan penelitian dengan judul "Penerapan Metode Pembelajaran Kooperatif Model Team Assisted Individualization Untuk Meningkatkan Prestasi Belajar Matematika Pada Siswa Kelas VII-B SMP Negeri 2 Ngimbang Tahun Pelajaran 2019/2020”

\section{METODE}

Penelitian ini merupakan penelitian tindakan (action research), karena penelitian dilakukan untuk memecahkan masalah pembelajaran di kelas. Penelitian ini juga termasuk penelitian deskriptif, sebab menggambarkan bagaimana suatu teknik pembelajaran diterapkan dan bagaimana hasil yang diinginkan dapat dicapai.
Menurut Oja dan Sumarjan (dalam Titik Sugiarti, 1997: 8) mengelompokkan penelitian tindakan menjadi empat macam yaitu, (a) guru sebagai peneliti; (b) penelitian tindakan kolaboratif; (c) simultan terintegratif; (d) administrasi sosial eksperimental.

Penelitian ini dilaksanakan sebanyak 3 siklus. Sebelum masuk pada siklus I dilakukan tindakan pendahuluan yang berupa identifikasi permasalahan. Observasi dilakukan pada tiap siklus, dan melakukan kegiatan pembelajaran berdasarkan kompetensi dasar yang ingin dicapai. Proses pembelajaran pada masing-masing siklus dikenai perlakuan yang sama (langkah-langkah kegiatan yang sama), dimana perlakuan dalam setiap putaran (siklus) terdiri dari empat komponen pokok yaitu perencanaan, tindakan, observasi dan refleksi. Tahapan kerja pada siklus III memiliki tahapan yang sama dengan kerja siklus I dan II. Pada siklus III, rencana tindakan disusun berdasarkan hasil refleksi siklus I dan II. Kegiatan-kegiatan yang dilakukan pada siklus III dimaksudkan untuk menyempumakan atau memperbaiki pelaksanaan pelatihan pada siklus II. Penelitian ini akan dilanjutkan ke siklus 
berikutnya sesuai dengan prosedur penelitian yang telah ditetapkan.

Langkah-langkah tersebut dapat digambarkan seperti berikut :

Gambar 3.1. Prosedur Penelitian Tindakan Kelas

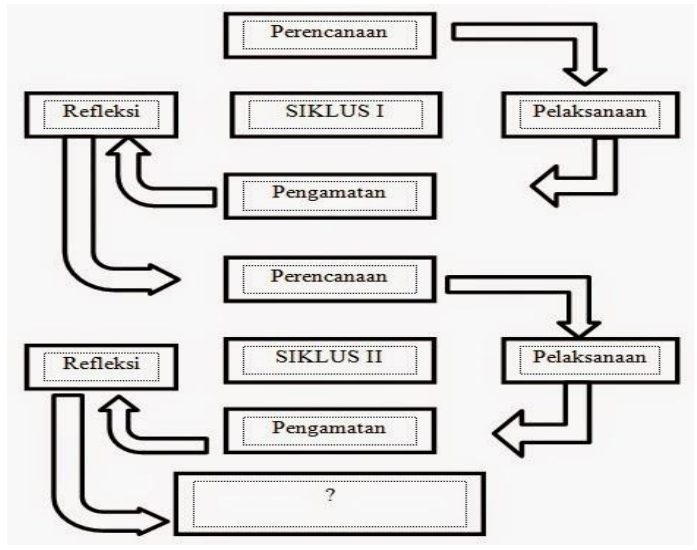

Sasaran penelitian ini adalah semua siswa kelas VII B SMP Negeri 2 Ngimbang tahun pelajaran 2019/2020 . Instrumen yang digunakan dalam penelitian ini terdiri dari: Silabus, Rencana Pelaksanaan Pembelajaran (RPP), lembar observasi, lembar kerja Siswa, lembar penilaian dan alat-alat pendukung lainnya.

Data-data yang diperlukan dalam penelitian ini diperoleh melalui observasi pengolahan metode pembelajaran kooperatif model Team Assisted Individualization, observasi aktivitas siswa dan guru dan tes formatif. Metode pengumpulan data yang diperlukan dalam penelitian ini menggunakan (1) metode observasi dengan cara melakukan pengamatan dan pencatatan lapangan mengenai proses kegiatan penelitian, (2) metode dokumentasi, yaitu teknik mengambil data dengan memeriksa dokumen yang telah ada sebelum penelitian berlangsung. Teknik dokumentasi sering dilakukan dengan melakukan pencatatan terhadap data yang ditemukan dalam suatu dokumen (Suharto, 2013: 28)

Teknik analisis data yang digunakan dalam penelitian ini meliputi :

a. Teknik analisis deskriptif kualitatif, yaitu suatu metode penelitian yang bersifat menggambarkan kenyataan atau fakta sesuai dengan data yang diperoleh dengan tujuan untuk mengetahui tingkat partisipasi atau aktivitas siswa selama proses pembelajaran

b. Teknik analisis data kuantitatif, yakni menganalisis tingkat keberhasilan atau persentase keberhasilan siswa setelah proses belajar mengajar dilakukan dengan cara memberikan evaluasi berupa soal tes tertulis atau tes formatif pada setiap akhir siklus. Teknik ini bertujuan untuk 
mengetahui prestasi belajar siswa yang tercermin pada tingkat ketuntasan belajar, baik secara individu maupun secara klasikal. Ketuntasan belajar untuk KTSP yang telah ditetapkan di SMP Negeri 2 Ngimbang adalah sebagai berikut :

1. Ketuntasan Individual

Setiap siswa dikatakan tuntas jika mendapatkan nilai minimal sesuai dengan KKM, yakni 65. Untuk menghitung nilai yang diperoleh setiap siswa, digunakan rumus sebagai berikut :

Nilai= Jumlah Skor diperoleh x skala (100)

Jumlah Skor Maksimum

\section{Ketuntasan Klasikal}

Sebuah kelas dikatakan tuntas belajar jika banyaknya siswa dalam kelas tersebut yang tuntas secara individual mencapai minimal $85 \%$. Untuk menghitung persentase ketuntasan belajar klasikal digunakan rumus sebagai berikut :

$$
T=\frac{\sum X}{\sum N} \times 100 \%
$$

Dengan : $T=$ Persentase ketuntasan klasikal

$$
\Sigma X=\text { Jumlah siswa }
$$

yang tuntas belajar

$$
\Sigma \mathrm{N}=\text { Jumlah semua }
$$

siswa di kelas

\section{HASIL DAN PEMBAHASAN}

\section{A. Kondisi Aktivitas Belajar Siswa}

Pada siklus I, Siswa kurang bersemangat bekerja secara kelompok dalam pembalajaran, Siswa belum terbiasa dengan kondisi belajar menggunakan model pembelajaran Kooperatif Model Team Assisted Individualization, siswa malas menjawab pertanyaan dan saling menunggu teman atau kelompok lainnya, aktivitas interaksi dalam kelompok, menyamakan persepsi, saling menanyakan dalam kelompok masing kurang, sebagian besar siswa masih kurang disiplin dan percaya diri dalam menjawab soal. Secara umum kondisi aktivitas siswa dalam proses pembelajaran siklus I masih belum memuaskan.

Pada siklus II, Kegiatan pembelajaran semakin mengarah pada pembelajaran metode Kooperatif Model Team $\quad$ Assisted 
p-ISSN: 2503-1228; e-ISSN: 2621-4172

Individualization, siswa sudah terbiasa dengan kelompoknya dan bekerja sama dengan kelompok dalam memecahkan soal-soal dari guru, siswa menjadi lebih antusias mencari tahu kebenaran jawaban, suasana pembelajaran sudah mulai terlihat aktif. Aspek yang masih belum terlihat adalah rasa percaya diri siswa dalam menyelesaikan masalah. Secara umum kondisi aktivitas siswa dalam proses pembelajaran siklus II lebih baik dibanding siklus I. Akan tetapi masih ada aspek-aspek yang perlu diperbaiki sehingga diperoleh kondisi aktivitas belajar siswa menjadi lebih baik.

Pada siklus III, sebagian besar siswa sudah semakin terbiasa dengan pembelajaran Kooperatif Model Team Assisted Individualization, siswa sudah terbiasa dengan kelompoknya dan bekerja sama dengan kelompok dalam memecahkan soal-soal dari guru, siswa lebih berani dan percaya diri, siswa menjadi lebih antusias mencari tahu kebenaran jawaban, suasana pembelajaran lebih "hidup" karena masing-masing kelompok secara bergantian ingin mempresentasikan hasil kerjanya dengan antusias. Dengan kondisi tersebut, maka secara umum kondisi aktivitas siswa dalam proses pembelajaran siklus III sudah sangat baik dan memuaskan.

Untuk mengetahui secara jelas perubahan kondisi aktivitas belajar siswa sebagaimana tersebut di atas disajikan dalam bentuk grafik berikut :

\section{Grafik 4.1}

Kondisi Aktivitas Belajar Siswa Pada Siklus I, II dan III

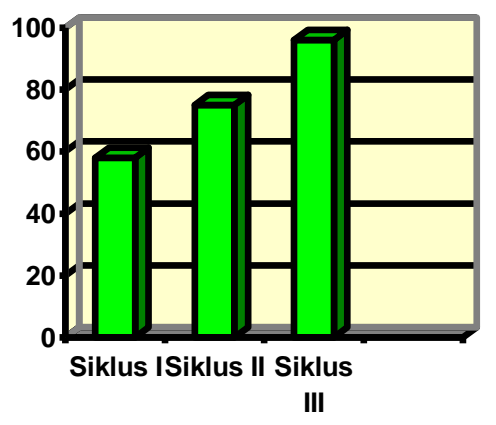

\section{B. Prestasi Belajar Siswa}

\section{Siklus I}

Adapun rekapitulasi data hasil belajar siswa pada siklus I adalah sebagai berikut: 
Tabel 4.1

Rekapitulasi Hasil Penilaian Tes formatif Siklus I

\begin{tabular}{|l|l|}
\hline Nilai Rata-rata Kelas & 62,73 \\
\hline Jumlah Siswa Tidak Tuntas Belajar & 15 \\
\hline Jumlah Siswa Tuntas Belajar & 29 \\
\hline Persentase Ketuntasan Klasikal & $65,6 \%$ \\
\hline
\end{tabular}

pencapaian nilai rata-rata tes formatif I sebesar 62,73, sedangkan jumlah siswa yang telah tuntas belajar sebanyak 29 siswa dari 44 siswa, dengan ketuntasan belajar klasikal sebesar 65,6\%. Hasil tersebut menunjukkan bahwa hasil belajar siswa pada siklus I masih belum optimal. Dengan hasil yang demikian maka perlu dilakukan tindakan-tindakan perbaikan misalnya (1) Guru perlu lebih terampil dalam memotivasi siswa dan lebih jelas dalam menyampaikan tujuan pembelajaran. Dimana siswa diajak untuk terlibat langsung dalam setiap kegiatan yang akan dilakukan, (2) Guru perlu mendistribusikan waktu secara baik dengan menambahkan informasi-informasi yang dirasa perlu dan memberi catatan, (3) Guru harus lebih terampil dan bersemangat dalam memotivasi siswa sehingga siswa bisa lebih antusias.

\section{Pada siklus II}

Adapun rekapitulasi data hasil belajar siswa pada siklus II adalah sebagai berikut:

Tabel 4.2

Rekapitulasi Hasil Penilaian Tes formatif Siklus II

\begin{tabular}{|l|l|}
\hline Nilai Rata-rata Kelas & $\mathbf{7 3 , 8 6}$ \\
\hline Jumlah Siswa Tidak Tuntas Belajar & 10 \\
\hline Jumlah Siswa Tuntas Belajar & $\mathbf{3 4}$ \\
\hline Persentase Ketuntasan Klasikal & $\mathbf{7 7 , 3} \%$ \\
\hline
\end{tabular}

Dari tabel di atas dapat diketahui bahwa nilai rata-rata siswa mengalami peningkatan, yakni dari 62,73 (siklus I) menjadi 73,86 pada siklus II. Selain itu juga dapat diketahui bahwa sebanyak 34 siswa dari 44 siswa $(77,3 \%)$ telah mencapai KKM atau telah tuntas belajar (pada siklus I terdapat 29 siswa atau 65,6\%). Dengan hasil tersebut maka dapat dikatakan bahwa hasil belajar siswa pada siklus II mengalami peningkatan jika dibanding pencapaian hasil belajar siswa pada siklus I. Peningkatan hasil belajar siswa pada siklus II tersebut tidak terlepas dari upaya guru memperbaiki proses pembelajaran berdasarkan hasil refleksi pembelajaran pada siklus I. Sehubungan dengan belum diperolehnya ketuntasan 
p-ISSN: 2503-1228; e-ISSN: 2621-4172

belajar secara klasikal pada siklus II, maka perlu dilakukan tindakan-tindakan perbaikan misalnya (1) Guru dalam memotivasi siswa hendaknya dapat membuat siswa lebih termotivasi selama proses belajar mengajar berlangsung, (2) Guru harus lebih dekat dengan siswa sehingga tidak ada perasaan takut dalam diri siswa baik untuk mengemukakan pendapat atau bertanya, (3) Guru harus lebih sabar dalam membimbing siswa merumuskan kesimpulan/menemukan konsep, (4) Guru harus mendistribusikan waktu secara baik sehingga kegiatan pembelajaran dapat berjalan sesuai dengan yang diharapkan, (5) Guru sebaiknya menambah lebih banyak contoh soal dan memberi soal-soal latihan pada siswa untuk dikerjakan pada setiap kegiatan belajar mengajar

\section{Siklus III}

Adapun rekapitulasi data hasil belajar siswa pada siklus III adalah sebagai berikut:

Tabel 4.3

Rekapitulasi Hasil Penilaian Tes formatif Siklus III

\begin{tabular}{|l|l|}
\hline Nilai Rata-rata Kelas & 87,5 \\
\hline Jumlah Siswa Tidak Tuntas Belajar & $\mathbf{3}$ \\
\hline Jumlah Siswa Tuntas Belajar & $\mathbf{4 1}$ \\
\hline Persentase Ketuntasan Klasikal & $\mathbf{9 3 , 3} \%$ \\
\hline
\end{tabular}

Dari tabel di atas dapat diketahui bahwa nilai rata-rata siswa mengalami peningkatan, yakni dari 62,73 (siklus I), 73,86 (siklus II) menjadi 87,5 pada siklus III. Selain itu juga dapat diketahui bahwa persentase ketuntasan klasikal juga mengalami peningkatan, yakni sebanyak 41 siswa dari 44 siswa $(93,3 \%)$ telah mencapai KKM atau telah tuntas belajar (pada siklus I terdapat 29 siswa atau 65,6\%) dan pada siklus II terdapat 34 siswa atau 77,3\%). Peningkatan hasil belajar siswa pada siklus III tersebut tidak terlepas dari upaya guru memperbaiki proses pembelajaran berdasarkan hasil refleksi pembelajaran pada siklus I dan II. Dengan demikian dapat dikatakan bahwa secara umum tingkat keberhasilan atau pencapaian aspek-aspek dalam pembelajaran pada siklus III ini sudah optimal.

Berdasarkan hasil penelitian pada siklus III sebagaimana tersebut di atas, data-data hasil penerapan metode pembelajaran kooperatif model Team 
Assisted Individualization dapat diuraikan sebagai berikut:

1) Selama proses belajar mengajar guru telah melaksanakan semua pembelajaran dengan baik. Meskipun ada beberapa aspek yang belum sempurna, tetapi persentase pelaksanaannya untuk masing-masing aspek sudah cukup optimal.

2) Berdasarkan data hasil pengamatan diketahui bahwa siswa aktif selama proses belajar berlangsung.

3) Kekurangan pada siklus-siklus sebelumnya sudah mengalami perbaikan dan peningkatan sehingga menjadi lebih baik.

4) Hasil belajar siswa pada siklus III mencapai ketuntasan.

Untuk mengetahui secara jelas perubahan data-data hasil belajar siswa selama 3 siklus sebagaimana tersebut di atas disajikan dalam bentuk tabel dan grafik berikut:

Tabel 4.4

Rekapitulasi Pencapaian Hasil Belajar Siswa Pada Siklus I, siklus II dan Siklus III

\begin{tabular}{|l|l|l|l|l|}
\hline No & $\begin{array}{l}\text { Hasil Belajar } \\
\text { Siswa }\end{array}$ & $\begin{array}{l}\text { Siklus } \\
\text { I }\end{array}$ & $\begin{array}{l}\text { Siklus } \\
\text { II }\end{array}$ & $\begin{array}{l}\text { Siklus } \\
\text { III }\end{array}$ \\
\hline 1. & $\begin{array}{l}\text { Rata-rata } \\
\text { Nilai }\end{array}$ & 62,73 & 73,86 & 87,50 \\
\hline 2. & $\begin{array}{l}\text { Persentase } \\
\text { Ketuntasan } \\
\text { Klasikal }\end{array}$ & $65,6 \%$ & $77,3 \%$ & $93,3 \%$ \\
\hline
\end{tabular}

Grafik 4.2

Tingkat Pencapaian Nilai Rata-rata dan Ketuntasan Klasikal Pada Siklus I, siklus II dan Siklus III

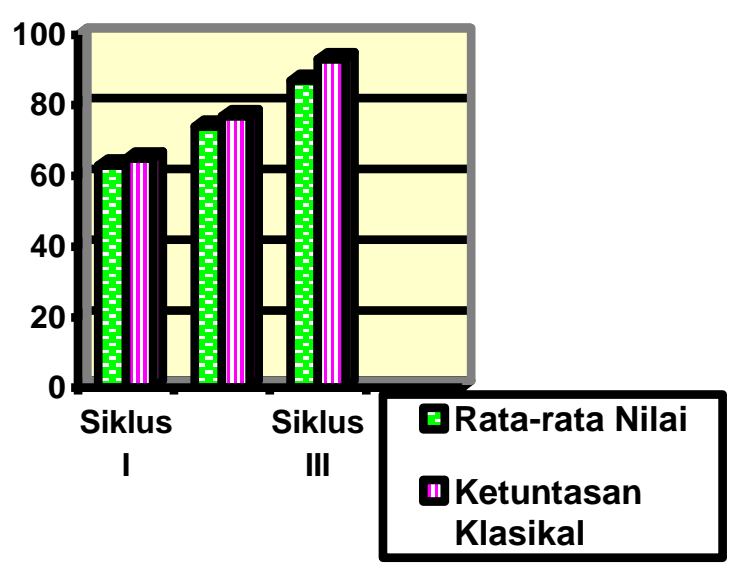

\section{KESIMPULAN}

Dari hasil analisis seluruh data beserta pembahasannya, maka dapat diambil satu kesimpulan bahwa penerapan metode pembelajaran kooperatif model team assisted individualization dapat 
meningkatkan prestasi belajar matematika siswa Kelas VII-B SMP Negeri 2

Ngimbang tahun pelajaran 2019/2020.

\section{DAFTAR PUSTAKA}

Wahyuni, Dwi. 2001. Studi Tentang Pembelajaran Kooperatif Terhadap Hasil Belajar Matematika. Malang: Program Sarjana Universitas Negeri Malang.

Ali, Muhammad. 1996. Guru Dalam Proses Belajar Mengajar. Bandung: Sinar Baru Algesindon.

Arikunto, Suharsimi. 1998. Prosedur Penelitian Suatu Pendekatan Praktek. Jakarta: Rineksa Cipta.

Arikunto, Suharsimi. 2001. Dasar-dasar Evaluasi Pendidikan. Jakarta: Bumi Aksara.

Arsyad, Azhar. 1997. Media Pembelajaran. Jakarta: PT. Raja Grafindo Persada.

Combs. Arthur. W. 1984. The Profesional Education of Teachers. Allin and Bacon, Inc. Boston.

Dahar, R.W. 1989. Teori-teori Belajar. Jakarta: Erlangga.

Departemen Pendidikan dan Kebudayaan, 1994. Petunjuk Pelaksanaan Proses Belajar Mengajar, Jakarta. Balai Pustaka.
Djamarah, Syaiful Bahri. 2000. Strategi Belajar Mengajar. Jakarta: Rineksa Cipta.

Felder, Richard M. 1994. Cooperative Learning in Technical Corse, (online), (Pcllld\My \% DocumentlCoop \% 20 Report.

Hamalik, Oemar. 1994. Media Pendidikan. Bandung: Citra Aditya Bakti.

Hasibuan. J.J. dan Moerdjiono. 1998. Proses Belajar Mengajar. Bandung: Remaja Rosdakarya.

Hudoyo, H. 1990. Strategi Belajar Mengajar Matematika. Malang: IKIP Malang.

Kemmis, S. dan Mc. Taggart, R. 1988. The Action Research Planner. Victoria Dearcin University Press.

Margono, S. 1996. Metodologi Penelitian Pendidikan. Jakarta: Rineksa Cipta.

Mursell, James ( - ). Succesfull Teaching (terjemahan). Bandung: Jemmars.

Ngalim, Purwanto M. 1990. Psikologi Pendidikan. Bandung: PT. Remaja Rosdakarya.

Nur, Muhammad. 1996. Pembelajaran Kooperatif. Surabaya. Universitas Negeri Surabaya.

Sardiman, A.M. 1996. Interaksi dan Motivasi Belajar Mengajar. Jakarta: Bina Aksara. 